\title{
Kajian Morfometri Rajungan (Portunus pelagicus) Linnaeus, 1758 (Crustacea: Portunidae) pada Dua Fase Bulan yang Berbeda di Perairan Desa Tunggulsari, Rembang
}

\author{
Wukir Berliana Pratiwi*, Ria Azizah Tri Nuraini, Widianingsih \\ Departemen IImu Kelautan, Fakultas Perikanan dan IImu Kelautan, Universitas Diponegoro \\ JI. Prof. H. Soedarto S.H, Tembalang, Semarang, Jawa Tengah 50275 Indonesia \\ *Corresponding author, e-mail: 8wukir88@gmail.com
}

\begin{abstract}
ABSTRAK: Fase bulan secara periodik mengalami perubahan dan menjadi faktor yang mempengaruhi perairan secara fisika, kimia, maupun biologi. Kondisi tersebut di wilayah perairan laut menimbulkan fenomena pasang surut yang memiliki pengaruh besar terhadap kehidupan biota laut seperti rajungan (Portunus pelagicus). Strategi penangkapan yang tepat dapat dilakukan dengan menentukan target satu spesies atau dengan cara melihat fase bulan. Penelitian ini bertujuan untuk melakukan kajian morfometri, nisbah kelamin, hubungan lebar berat, dan tingkat kematangan gonad rajungan (Portunus pelagicus) yang tertangkap nelayan pada fase bulan purnama dan bulan mati dari Perairan Desa Tunggulsari, Rembang. Pengambilan data dilakukan terhadap rajungan (Portunus pelagicus) yang tertangkap oleh nelayan dari perairan Desa Tunggulsari. Kegiatan penelitian dilakukan pada tanggal 9 Januari 2020, 28 Januari 2020, 10 Februari 2020, 25 Februari 2020, 10 Maret 2020, dan 24 Maret 2020. Hasil penelitian berdasarkan uji T statistik menunjukkan bahwa ada perbedaan komposisi rajungan dari fase bulan purnama dan bulan mati dengan selisih yang tidak signifikan. Rajungan yang tertangkap pada fase bulan purnama memiliki rata-rata ukuran berat dan lebar yang lebih kecil dibandingkan pada fase bulan mati. Analisis power curve hubungan lebar dan berat rajungan yang ada di perairan Desa Tunggulsari bersifat allometrik negatif yang berarti pertumbuhan lebar karapas lebih cepat dibandingkan beratnya.
\end{abstract}

Kata kunci: Rajungan; Portunus pelagicus; komposisi; bulan purnama; bulan mati

\section{Study of Blue Swimming Crab (Portunus Pelagicus) Linnaeus, 1758 (Crustacea: Portunidae) Morphometry in Two Different Moon Phases on Tunggulsari Waters, Rembang}

\begin{abstract}
The lunar phase periodically changes and becomes a factor that affects the waters physically, chemically, and biologically. These conditions in the marine waters cause tidal phenomena which have a major influence on marine life such as blue swimming crab (Portunus pelagicus). The right fishing strategy can be done by determining the target of one species or by looking at the phases of the moon. This study aims to study the morphometry, sex ratio, weightwidth relationship, and maturity level of the crab gonads (Portunus pelagicus) caught by fishermen in the full moon and new moon phases of the Tunggulsari Waters, Rembang. The method used in this research is descriptive exploratory. Research activities were carried out on January 9, 2020, January 28, 2020, February 10, 2020, February 25, 2020, March 10, 2020, and March 24, 2020. The results of the study based on the statistical $T$ test showed that there was an insignificant difference in the catch of the full moon and new moon phases. The crabs that are caught in the full moon phase have an average size of weight and width that is smaller than in the new moon phase. Analysis of the relationship between the width and weight of small crabs in the waters of Tunggulsari Waters is negative allometric, which means that the carapace width grows faster than its weight.
\end{abstract}

Keywords: Portunus pelagicus; composition; full moon; new moon 


\section{PENDAHULUAN}

Di Perairan Indo Pasifik terdapat lebih dari 234 jenis kepiting dan 124 jenis ditemukan di Perairan Indonesia. Jenis kepiting yang populer sebagai bahan makanan adalah Portunus sp. yang biasa disebut rajungan (Hastuti et al. 2012). Perairan Rembang terletak di Pantai Utara Jawa Tengah dan termasuk ke dalam wilayah Kabupaten Rembang, Provinsi Jawa Tengah. Hasil produksi perikanan tangkap dari Perairan Rembang pada tahun 2018 mencapai angka 42.452 .505 kg. sedangkan rajungan mencapai angka produksi sebesar $5.584 \mathrm{~kg}$ dengan nilai produksinya adalah Rp. 518.860.000 (Badan Pusat Statistik Kabupaten Rembang, 2019). Rajungan merupakan salah satu sumber daya yang banyak hidup di perairan Indonesia termasuk di wilayah Perairan Rembang, di mana lokasi ini dapat dijadikan sentra penangkapan rajungan khususnya Desa Tunggulsari.

Fase bulan secara periodik selama satu bulan mengalami perubahan yang berulang dalam satu tahunnya dan menjadi salah satu faktor yang mempengaruhi perairan secara fisika, kimia, maupun biologi. Kondisi tersebut berakibat terhadap tingkah laku biota yang hidup di dalamnya (Putra et al. 2019). Pengaruh fase bulan dapat dikatakan mempengaruhi pola pencarian makan, migrasi, atau reproduksi rajungan di Perairan Desa Tunggulsari sehingga dapat menyebabkan perbedaan komposisi rajungan yang diperoleh. Saat fase bulan purnama, rajungan muda-dewasa cenderung banyak menghabiskan waktunya di kolom perairan untuk mencari makan atau melakukan perkawinan. Hal ini dikarenakan pada saat bulan purnama identik dengan pasang tinggi dan mempengaruhi keaktifan rajungan di suatu perairan (Wiyono dan Ihsan, 2015). Menurut Hasly et al., (2019) pada penelitiannya, rajungan memiliki ketertarikan terhadap cahaya (fototaksis positif) yang menyebabkan rajungan menjadi aktif di perairan. Menurut Erlinda et al. (2016), hal tersebut yang dapat menyebabkan komposisi rajungan yang tertangkap pada fase bulan purnama lebih banyak dibandingkan bulan mati. Fenomena perubahan fase bulan bagi nelayan Desa Tunggulsari umum dikenal sebagai penanda kegiatan penangkapan sumber daya laut seperti sedikit atau banyaknya rajungan yang tertangkap pada bulan purnama dan bulan mati. Fase bulan di wilayah perairan laut menyebabkan naik turunnya permukaan laut secara periodik selama interval waktu tertentu yang disebut dengan fenomena pasang surut. Informasi mengenai dinamika populasi dan kajian biologi dari rajungan (Portunus pelagicus) penting bagi penentu kebijakan dan pengelolaan dalam mengukur kelestarian populasinya. Berdasarkan kondisi yang ada, diperlukan kajian mengenai keadaan biologi rajungan (Portunus pelagicus) dari Perairan Desa Tunggulsari, sehingga penelitian ini penting untuk dilakukan agar dapat memberikan informasi bagi nelayan dalam upaya penangkapan rajungan (Portunus pelagicus).

\section{MATERI DAN METODE}

Materi yang digunakan dalam penelitian adalah rajungan (Portunus pelagicus) yang ditangkap bersama nelayan yang berasal dari Perairan Desa Tunggulsari, Rembang, Jawa Tengah menggunakan alat tangkap bubu. Pengambilan data parameter lingkungan digunakan sebagai data pendukung dalam penelitian. Penentuan lokasi pengambilan data rajungan dan parameter lingkungan dilakukan berdasarkan pada kegiatan nelayan pada saat melaut dan mengacu pada daerah wilayah tangkapan rajungan di Perairan Desa Tunggulsari. Pengambilan data berupa morfometri rajungan meliputi ukuran panjang, lebar, berat, jenis kelamin, dan tingkat kematangan gonad rajungan. Sedangkan data parameter lingkungan yang diambil meliputi suhu, salinitas, DO, pH, kedalaman, kecerahan. Pengambilan data dilakukan bersamaan dengan kegiatan penangkapan rajungan oleh nelayan sekitar pukul 06.00-07.00 WIB dengan 3 kali pengulangan pengukuran di perairan Desa Tunggulsari. Pengumpulan data pada penelitian ini menggunakan metode survei yang bersifat deskriptif dengan cara melakukan observasi secara langsung terhadap sampel yang menjadi objek penelitian sehingga dapat menunjang terbentuknya penggambaran keadaan pada suatu objek pada lokasi penelitian (Natania et al., 2017).

Analisis data yang dilakukan adalah sebagai berikut: (1) Analisis ukuran rajungan, untuk mengetahui pengelolaan rajungan berkaitan dengan pemanfaatannya pada suatu perairan (Damora dan Nurdin, 2016). Nisbah kelamin, untuk menunjukkan jumlah individu jantan dan betina 
dalam suatu populasi dengan menggunakan rumus menurut Effendie (2002). Nilai selang kepercayaan $95 \%$ dibandingkan antara nilai $\lambda^{2}$ hitung dengan nilai $\lambda_{\text {tabel, }}$ kemudian keputusan yang diambil untuk mengetahui keseimbangan nisbah kelamin pada suatu populasi yaitu: $\lambda^{2}$ hitung $>\lambda_{\text {tabel }}$ : Nisbah kelamin jantan dan betina tidak seimbang, $\lambda^{2}$ hitung $<\lambda_{\text {tabel }}$ : Nisbah kelamin jantan dan betina seimbang, $\lambda^{2}$ hitung $=\lambda_{\text {tabel }}$ : Nisbah kelamin jantan dan betina seimbang. Analisis power curve hubungan lebar dan berat, bertujuan untuk mengetahui pola pertumbuhan (Effendi, 2002). Jika $b=3$ maka pola pertumbuhan isometrik (pola pertumbuhan lebar sama dengan pertumbuhan berat); Jika $b>3$ maka pola pertumbuhan allometrik positif (pertumbuhan berat lebih cepat dari pada pertumbuhan lebar); Jika $b<3$ maka pola pertumbuhan allometrik negatif (pertumbuhan lebar lebih cepat dari pada pertumbuhan berat). Faktor kondisi, untuk mengetahui kesesuaian perairan dengan pertumbuhan biota, dapat dihitung dengan rumus menurut Rypel dan Richter (2008). Analisis Tingkat Kematangan Gonad (TKG), analisis distribusi tingkat kematangan gonad rajungan (Portunus pelagicus) yang berasal dari keseluruhan kegiatan penangkapan diperoleh dengan menghitung jumlah rajungan betina yang mengalami kematangan gonad disajikan dalam bentuk grafik dan tabel dan bersumber dari Asosiasi Pengelolaan Rajungan Indonesia (2017).

\section{HASIL DAN PEMBAHASAN}

Hasil penelitian menunjukkan bahwa rajungan yang tertangkap pada fase bulan purnama lebih banyak dibandingkan dengan fase bulan mati, yaitu sejumlah 146 ekor. Untuk menyatakan perbedaannya, maka dilakukan uji statistik T. Hasil pengujian menurut hipotesis adalah "tidak ada perbedaan hasil tangkapan rajungan pada bulan purnama dan bulan mati". Hal ini disebabkan oleh selisih hasil tangkapan yang tidak signifikan, hanya berbeda sejumlah 12 ekor. Namun, apabila dilihat dari hasil penelitian, rajungan yang tertangkap pada fase bulan mati memiliki ukuran tubuh yang lebih besar, dilihat dari lebar karapas. Kisaran lebar karapas pada rajungan di fase bulan mati adalah 71-134 mm atau 7,1-13,4 cm. Sedangkan pada fase bulan purnama berkisar antara 49-136 $\mathrm{mm}$ atau 4,9-13,6 $\mathrm{cm}$. Hal ini menandakan bahwa rajungan dewasa lebih banyak melakukan aktivitas di perairan pada saat fase bulan mati. Hasil penelitian sesuai dengan pernyataan Wiyono dan Ihsan (2015) yang menyebutkan bahwa pada saat fase bulan purnama, rajungan muda-dewasa cenderung banyak menghabiskan waktunya di kolom perairan untuk mencari makan atau melakukan perkawinan. Hal ini dikarenakan pada saat bulan purnama identik dengan pasang tinggi dan mempengaruhi keaktifan rajungan di suatu perairan.

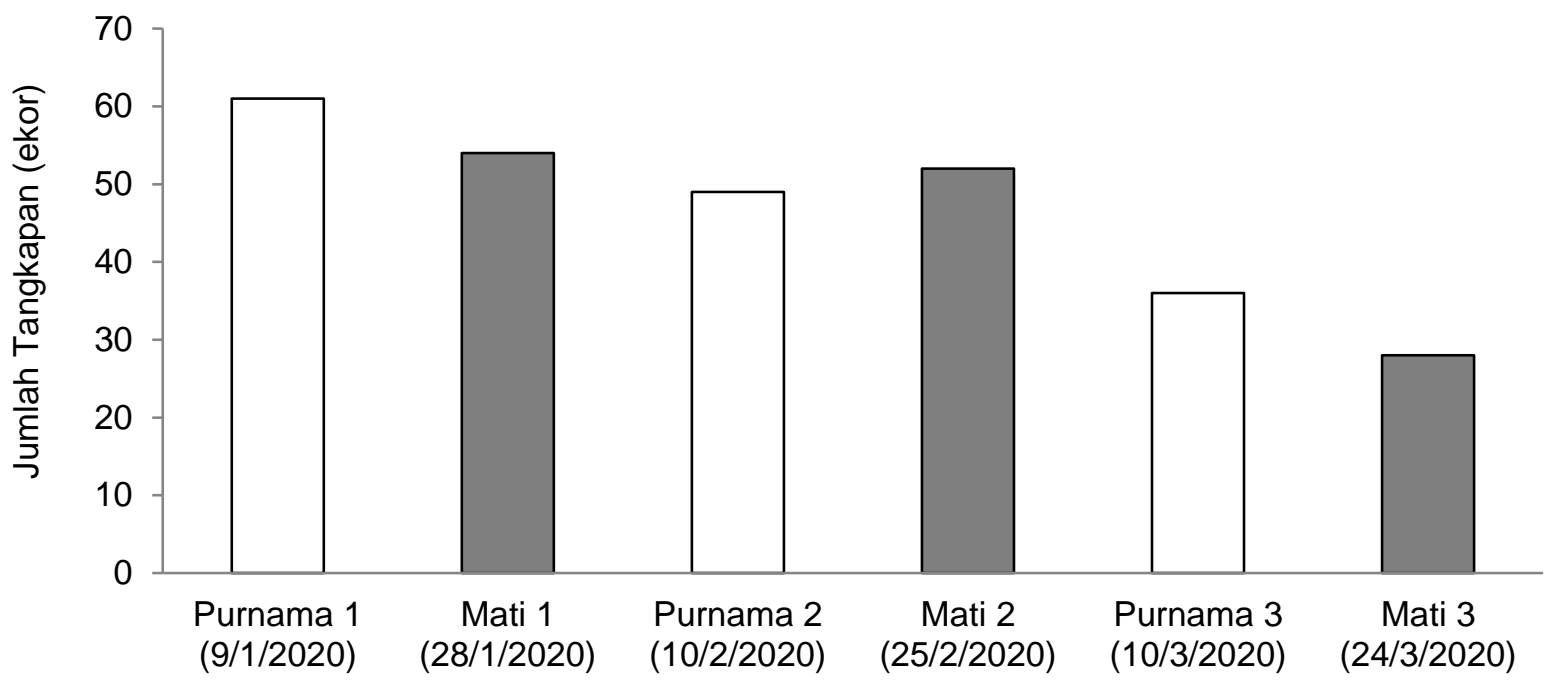

Waktu Pengambilan Data

Gambar 1. Komposisi Rajungan Total pada Fase Bulan Purnama dan Bulan Mati di Perairan Desa Tunggulsari 
Menurut Hasly et al., (2019) pada penelitiannya, rajungan memiliki ketertarikan terhadap cahaya (fototaksis positif) yang menyebabkan rajungan menjadi aktif di perairan. Menurut Erlinda et al., (2016), hal tersebut yang dapat menyebabkan komposisi rajungan yang tertangkap pada fase bulan purnama lebih banyak dibandingkan bulan mati. Apabila diperhatikan sesuai hasil pengukuran parameter lingkungan di perairan Desa Tunggulsari, kadar oksigen terlarut (DO) yang terukur pada fase bulan mati adalah sebesar 8,3-8,7 mg/l. Hasil tersebut menurut Soliha et al., (2016) adalah kondisi di mana banyak terdapat plankton yang di perairan, yang merupakan makanan rajungan. Hal ini berhubungan dengan banyaknya jumlah rajungan dewasa yang tertangkap, pada kondisi itulah akan banyak rajungan dewasa yang mencari makan, sejalan dengan karakteristik rajungan yang tertarik dengan cahaya (fototaksis positif) sehingga cahaya bulan berpengaruh terhadap keinginan rajungan untuk mencari makan (Azis et al., 2016).

Persentase dan rasio perbandingan antara rajungan jantan dan betina (Tabel 1) menghasilkan keterangan bahwa pada fase bulan purnama 1, mati 1, dan mati 3 rajungan yang tertangkap antara jantan dan betina adalah seimbang. Sedangkan pada fase bulan purnama 2, mati 2, dan purnama 3 dikatakan tidak seimbang. Perbedaan hasil tersebut kemungkinan dikarenakan oleh adanya perubahan perilaku dari masing-masing individu dalam beradaptasi menemukan habitat yang sesuai untuk ditinggali, pengaruh dari kegiatan penangkapan, mortalitas serta rekruitmen (Agus et al., 2016). Pada musim penghujan saat suhu perairan menurun, rajungan akan berada pada kondisi tidak aktif, rajungan akan banyak menghabiskan waktu dengan mengubur diri di dalam pasir untuk menjaga suhu tubuh agar tetap stabil. Kemungkinan bahwa rajungan akan bermigrasi ke perairan yang lebih dalam juga dapat terjadi. Hal tersebut dapat menjadi indikator terjadinya perbedaan rasio tangkapan selama penelitian (Ningrum et al., 2015).

Tabel 1. Nisbah Kelamin Rajungan Fase Bulan Purnama dan Fase Bulan Mati

\begin{tabular}{cccccccc}
\hline \multirow{2}{*}{ Fase Bulan } & \multicolumn{2}{c}{ Jumlah (ekor) } & \multicolumn{2}{c}{ Nisbah Kelamin (rasio) } & \multirow{2}{*}{$X^{2}{ }_{\text {hitung }} \mathcal{X}_{\text {tabel(a0,05) }}$} & \multirow{2}{*}{ Keterangan } \\
\cline { 2 - 5 } & Jantan & Betina & Jantan & Betina & & \\
\hline Purnama 1 & 26 & 35 & 0,74 & 1,34 & 1,327 & 1,5 & Seimbang \\
Mati 1 & 28 & 26 & 1.07 & 0,92 & 0,074 & 1,325 & Seimbang \\
Purnama 2 & 30 & 19 & 1,57 & 0,63 & 2,469 & 1,2 & Tidak Seimbang \\
Mati 2 & 31 & 21 & 1,47 & 0,67 & 1,923 & 1,275 & Tidak Seimbang \\
Purnama 3 & 14 & 22 & 0,63 & 1,57 & 1,77 & 0,875 & Tidak Seimbang \\
Mati 3 & 13 & 15 & 0,86 & 1,15 & 0,142 & 0,325 & Seimbang \\
\hline
\end{tabular}

Tabel 2. Distribusi Ukuran Lebar Karapas Rajungan pada Fase Bulan Purnama

\begin{tabular}{|c|c|c|c|c|}
\hline \multirow[b]{2}{*}{ Kelas (mm) } & \multicolumn{3}{|c|}{ Frekuensi } & \multirow[b]{2}{*}{ Jumlah } \\
\hline & $\begin{array}{l}\text { Purnama } 1 \\
(9 / 1 / 2020)\end{array}$ & $\begin{array}{l}\text { Purnama } 2 \\
(10 / 2 / 2020)\end{array}$ & $\begin{array}{l}\text { Purnama } 3 \\
(10 / 3 / 2020)\end{array}$ & \\
\hline $49-59$ & 0 & 2 & 1 & 3 \\
\hline $60-70$ & 0 & 3 & 2 & 5 \\
\hline $71-81$ & 5 & 1 & 0 & 6 \\
\hline $82-92$ & 12 & 5 & 0 & 17 \\
\hline $93-103$ & 25 & 17 & 13 & 55 \\
\hline 104-114 & 13 & 14 & 11 & 38 \\
\hline $115-125$ & 6 & 5 & 8 & 19 \\
\hline $126-136$ & 0 & 2 & 1 & 3 \\
\hline Jumlah & 61 & 49 & 36 & 146 \\
\hline
\end{tabular}


Tabel 3. Distribusi Ukuran Lebar Karapas Rajungan pada Fase Bulan Mati

\begin{tabular}{|c|c|c|c|c|}
\hline \multirow[b]{2}{*}{ Kelas (mm) } & \multicolumn{3}{|c|}{ Frekuensi } & \multirow[b]{2}{*}{ Jumlah } \\
\hline & $\begin{array}{r}\text { Mati 1 } \\
(28 / 1 / 2020)\end{array}$ & $\begin{array}{c}\text { Mati } 2 \\
(25 / 2 / 2020)\end{array}$ & $\begin{array}{c}\text { Mati 3 } \\
(24 / 3 / 2020)\end{array}$ & \\
\hline $71-78$ & 6 & 1 & 1 & 8 \\
\hline $79-86$ & 6 & 1 & 2 & 9 \\
\hline $87-94$ & 12 & 13 & 2 & 27 \\
\hline $95-102$ & 13 & 10 & 7 & 30 \\
\hline $103-110$ & 10 & 23 & 8 & 41 \\
\hline $111-118$ & 5 & 3 & 6 & 14 \\
\hline $119-126$ & 2 & 0 & 2 & 4 \\
\hline $127-134$ & 0 & 1 & 0 & 1 \\
\hline Jumlah & 54 & 52 & 28 & 134 \\
\hline Total & & 134 & & \\
\hline
\end{tabular}

Tabel 4. Distribusi Ukuran Berat Rajungan pada Fase Bulan Purnama

\begin{tabular}{|c|c|c|c|c|}
\hline \multirow[b]{2}{*}{ Kelas (gr) } & \multicolumn{3}{|c|}{ Frekuensi } & \multirow[b]{2}{*}{ Jumlah } \\
\hline & $\begin{array}{l}\text { Purnama } 1 \\
(9 / 1 / 2020)\end{array}$ & $\begin{array}{l}\text { Purnama } 2 \\
(10 / 2 / 2020)\end{array}$ & $\begin{array}{l}\text { Purnama } 3 \\
(10 / 3 / 2020)\end{array}$ & \\
\hline $35-53$ & 0 & 4 & 0 & 4 \\
\hline $54-72$ & 4 & 7 & 6 & 17 \\
\hline $73-91$ & 37 & 17 & 11 & 65 \\
\hline $92-110$ & 18 & 15 & 5 & 38 \\
\hline 111-129 & 1 & 2 & 6 & 9 \\
\hline $130-148$ & 1 & 2 & 2 & 5 \\
\hline 149-167 & 0 & 0 & 3 & 3 \\
\hline $168-186$ & 0 & 2 & 3 & 5 \\
\hline Jumlah & 61 & 49 & 36 & 146 \\
\hline Total & & 146 & & \\
\hline
\end{tabular}

Tabel 5. Distribusi Ukuran Berat Rajungan pada Fase Bulan Mati

\begin{tabular}{|c|c|c|c|c|}
\hline \multirow[t]{2}{*}{ Kelas (gr) } & \multicolumn{3}{|c|}{ Frekuensi } & \multirow[t]{2}{*}{ Jumlah } \\
\hline & $\begin{array}{c}\text { Mati 1 } \\
(28 / 1 / 2020)\end{array}$ & $\begin{array}{c}\text { Mati } 2 \\
(25 / 2 / 2020)\end{array}$ & $\begin{array}{c}\text { Mati 3 } \\
(24 / 3 / 2020)\end{array}$ & \\
\hline $33-57$ & 0 & 10 & 3 & 13 \\
\hline $58-82$ & 21 & 16 & 8 & 45 \\
\hline $83-107$ & 25 & 22 & 9 & 56 \\
\hline $107-131$ & 4 & 3 & 5 & 12 \\
\hline $132-156$ & 2 & 0 & 3 & 5 \\
\hline $157-180$ & 2 & 0 & 0 & 2 \\
\hline 181-205 & 0 & 0 & 0 & 0 \\
\hline $206-230$ & 0 & 1 & 0 & 1 \\
\hline Jumlah & 54 & 52 & 28 & 134 \\
\hline Total & & 134 & & \\
\hline
\end{tabular}


Journal of Marine Research Vol 10, No.1 Februari 2021, pp. 109-116

Tabel 6. Hasil Analisis Hubungan Lebar dan Berat Rajungan (Portunus pelagicus) di Perairan Desa Tunggulsari

\begin{tabular}{lccccccl}
\hline $\begin{array}{c}\text { Fase } \\
\text { Bulan }\end{array}$ & $\mathrm{n}$ & $\mathrm{a}$ & $\mathrm{b}$ & $\mathrm{R}^{2}$ & $\mathrm{~W}=\mathrm{aL}$ & $\begin{array}{c}\text { Faktor } \\
\text { Kondisi }\end{array}$ & $\begin{array}{c}\text { Pola } \\
\text { Pertumbuhan }\end{array}$ \\
\hline Purnama 1 & 61 & 4,226 & 0,6654 & 0,3804 & $4,226 \mathrm{~L}^{0,6654}$ & 101,366 & $\begin{array}{l}\text { Allometrik } \\
\text { Negatif }\end{array}$ \\
Mati 1 & 54 & 0,156 & 1,3905 & 0,6049 & $0,156 \mathrm{~L}^{1,3905}$ & 89,752 & $\begin{array}{l}\text { Allometrik } \\
\text { Negatif }\end{array}$ \\
Purnama 2 & 49 & 13,304 & 0,4069 & 0,0639 & $13,304 \mathrm{~L}^{0,4069}$ & 109,936 & $\begin{array}{l}\text { Allometrik } \\
\text { Negatif }\end{array}$ \\
Mati 2 & 52 & $2,711 \times 10^{-4}$ & 2,728 & 0,6736 & $2,711 \times 10^{-4} \mathrm{~L}^{2,728}$ & 114,276 & $\begin{array}{l}\text { Allometrik } \\
\text { Negatif }\end{array}$ \\
Purnama 3 & 36 & 4,337 & 0,6779 & 0,1577 & $4,337 \mathrm{~L}^{0,6779}$ & 96,382 & $\begin{array}{l}\text { Allometrik } \\
\text { Negatif }\end{array}$ \\
Mati 3 & 28 & $8,790 \times 10^{-5}$ & 2,9857 & 0,9541 & $8,790 \times 10^{-5} \mathrm{~L}^{2,9857}$ & 102,885 & $\begin{array}{l}\text { Allometrik } \\
\text { Negatif }\end{array}$ \\
\hline
\end{tabular}

Hasil penelitian menunjukkan bahwa terdapat 72 dari 280 ekor rajungan yang tertangkap pada fase bulan purnama maupun bulan mati masih berukuran $\leq 10 \mathrm{~cm}$. Nelayan di Desa Tunggulsari masih melanggar aturan dan dapat dikatakan belum konservatif dalam kegiatan pengelolaan penangkapan rajungan. Kegiatan penangkapan rajungan dengan ukuran $\leq 10 \mathrm{~cm}$ berarti tidak mendukung pengelolaan perikanan yang berkelanjutan karena menghambat atau mengurangi rekrutmen stok rajungan pada suatu perairan. Perbedaan ukuran tubuh dari rajungan dapat dipengaruhi oleh beberapa faktor. Semakin jauh dari pantai, rata-rata ukuran lebar karapas rajungan akan meningkat dan konstan pada jarak tertentu. Sehingga diketahui bahwa wilayah tangkapan menjadi salah satu faktor yang juga mempengaruhi ukuran lebar karapas selain faktor lingkungan, dan tingkat penangkapan yang berbeda pada setiap perairan. Menurut Ernawati et al. (2014), tingkat penangkapan yang tinggi menyebabkan banyak rajungan tertangkap termasuk rajungan dengan ukuran kecil atau juvenil yang belum siap tangkap.

Analisis hubungan lebar dan berat rajungan dilakukan untuk mengetahui pola pertumbuhan rajungan, untuk mengetahui pengaruh satu sama lain antara pertumbuhan lebar karapas dan penambahan berat tubuh dari rajungan.

Pola pertumbuhan rajungan pada kedua fase bulan bersifat allometrik, dan karena nilai $b<3$, maka pola pertumbuhannya adalah allometrik negatif. Hal ini berarti pertumbuhan lebar karapas rajungan lebih cepat dibandingkan pertumbuhan beratnya (Tabel 6). Grafik pola pertumbuhan rajungan dapat dilihat pada Gambar 2. Hasil dari perhitungan menunjukkan bahwa lebar karapas memiliki pengaruh terhadap berat rajungan. Berdasarkan analisis hubungan lebar dan berat rajungan di perairan Desa Tunggulsari menunjukkan nilai $b<3$. Maka pola pertumbuhan bersifat allometrik, dan karena nilai $b<3$ maka pola pertumbuhannya allometrik negatif, baik pada rajungan yang tertangkap pada fase bulan purnama dan bulan mati. Hasil ini menggambarkan bahwa pertumbuhan lebar karapas rajungan lebih dominan disbanding pertumbuhan berat tubuhnya, dapat diasumsikan bahwa hal ini disebabkan oleh rendahnya ketersediaan stok makanan di lokasi penangkapan di perairan Desa Tunggulsari. Kembaren dan Surahman (2018) menjelaskan bahwa ketersediaan pakan alami pada habitat rajungan akan menyebabkan pertumbuhannya menjadi relatif cepat, karena persediaan energi untuk melakukan proses metabolisme dapat tercukupi. Sedangkan kegiatan penangkapan yang tinggi menyebabkan terganggunya proses pertumbuhan rajungan. Perbedaan laju pertumbuhan dengan ukuran karapas menunjukkan bahwa kecepatan pertumbuhan dari setiap individu adalah tidak sama, hal tersebut disebabkan oleh kemampuan dalam memanfaatkan energi serta meminimalisir pengaruh faktor fisiologi dan faktor lain yang berbeda. Pola pertumbuhan juga ditentukan oleh strategi hidup dan kondisi lingkungan.

Tingkat Kematangan Gonad (TKG) dianalisis pada rajungan betina yang tertangkap pada fase bulan purnama dan bulan mati di perairan Desa Tunggulsari. Berdasarkan total rajungan betina yang tertangkap yaitu sebanyak 138 ekor, 76 ekor tertangkap pada fase bulan purnama dan 62 ekor tertangkap pada fase bulan mati. 
Tabel 7. Tingkat Kematangan Gonad Rajungan (TKG) pada Fase Bulan Purnama dan Bulan Mati.

\begin{tabular}{lccc}
\hline \multirow{2}{*}{ Fase Bulan } & \multicolumn{3}{c}{ Tingkat Kematangan Gonad } \\
\cline { 2 - 4 } & 1 & 2 & 3 \\
\hline Purnama 1 & 7 ekor & 23 ekor & 5 ekor \\
Mati 1 & 1 ekor & 20 ekor & 5 ekor \\
Purnama 2 & 2 ekor & 12 ekor & 5 ekor \\
Mati 2 & 2 ekor & 14 ekor & 5 ekor \\
Purnama 3 & 1 ekor & 13 ekor & 8 ekor \\
Mati 3 & 0 ekor & 5 ekor & 10 ekor \\
\hline
\end{tabular}

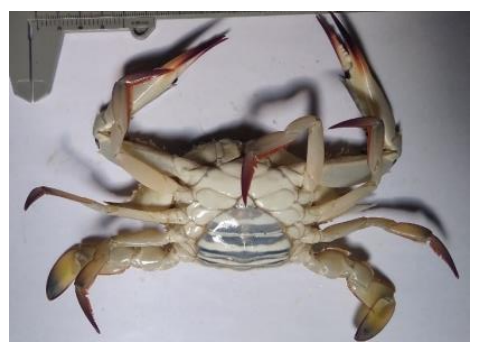

TKG 2

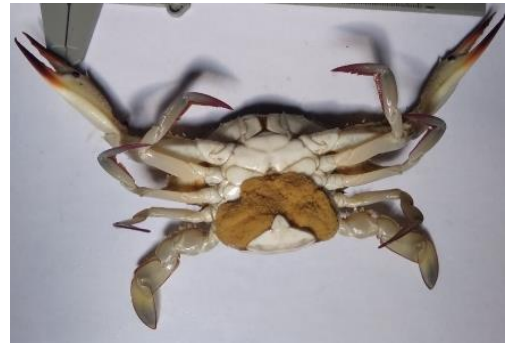

TKG 5

Gambar 2. Tingkat Kematangan Gonad pada Rajungan Betina di Perairan Desa Tunggulsari.

Hasil menunjukkan bahwa rajungan betina bertelur yang tertangkap pada fase bulan mati memiliki ukuran lebar karapas yang lebih tinggi dibandingkan rajungan betina bertelur yang tertangkap pada fase bulan purnama.

Menurut Ernawati et al. (2014), puncak musim pemijahan di wilayah perairan laut utara Jawa khususnya di wilayah Perairan Pati ada pada bulan Oktober. Sedangkan puncak musim peminjahan di perairan Lampung Timur menurut Zairion (2015) adalah pada bulan April-Juni dan SeptemberOktober/November, dan bulan Januari-Maret dan Juni-Agustus pada perairan Brebes menurut Sunarto (2012). Hal ini dapat menjelaskan bahwa tingkat kematangan gonad dapat menjadi berbeda sesuai lokasi penelitian yang diambil, yang mana salah satu penyebabnya ialah perbedaan musim pemijahan. Temperatur perairan juga mempengaruhi tigkat kematangan gonad rajungan, karena pada perairan yang hangat, perkembangan ovarium akan berjalan lebih cepat.

Rajungan betina yang tertangkap di perairan Desa Tunggulsari menunjukkan hasil bahwa rajungan yang belum matang gonad relatif lebih tinggi dibandingkan dengan rajungan matang gonad. Sebaran tingkat kematangan gonad menunjukkan bahwa terdapat rajungan yang berukuran $\leq 10 \mathrm{~cm}$ yang sudah mencapai tingkat kematangan 3 . Hal tersebut menjelaskan bahwa pada kondisi tertentu, rajungan tersebut dapat mencapai matang gonad lebih cepat. Menurut Ernawati et al. (2014), puncak musim pemijahan di wilayah perairan laut utara Jawa khususnya di wilayah Perairan Pati ada pada bulan Oktober. Sedangkan puncak musim peminjahan dapat menjelaskan bahwa tingkat kematangan gonad dapat menjadi berbeda sesuai lokasi penelitian yang diambil, yang mana salah satu penyebabnya ialah perbedaan musim pemijahan. Suhu perairan juga mempengaruhi tigkat kematangan gonad rajungan, karena pada perairan yang hangat, perkembangan ovarium akan berjalan lebih cepat.

\section{KESIMPULAN}

Berdasarkan hasil penelitian, dapat disimpulkan bahwa komposisi rajungan pada fase bulan purnama dan bulan mati di perairan Desa Tunggulsari memiliki selisih yang tidak signifikan. Perbedaan fase bulan memberikan pengaruh terhadap komposisi rajungan yang tertangkap. 


\section{DAFTAR PUSTAKA}

Agus, S.B., Zulbainarni, N., Sunuddin, A., Subarno, T., Nugraha, A.H., Rahimah, I., Alamsyah, A., Rachmi, R. \& Jihad. 2016. Distribusi Spasial Rajungan (Portunus pelagicus) pada Musim Timur di Perairan Pulau Lancang, Kepulauan Seribu. Jurnal IImu Pertanian Indonesia, 21(3):209-218.

Azis, Y., Fujaya, M.Y. \& Karim. 2016. Pengaruh Berbagai Intensitas Cahaya Terhadap Laju Pemangsaan Pakan dan Sintasan Larva Rajungan (Portunus pelagicus) Stadia Zoea. Jurnal Sains \& Teknologi, 16(1):62-69.

Damora, A. \& Nurdin, E. 2016. Beberapa Aspek Biologi Rajungan (Portunus pelagicus) di Perairan Labuhan Maringgai, Lampung Timur. Jurnal Bawal, 8(1):13-20.

Erlinda, S., Sara, L.\& Irawati, N. 2016. Makanan Rajungan (Portunus pelagicus) di Perairan Lakara Kabupaten Konawe Selatan, Sulawesi Tenggara. Jurnal Manajemen Sumber Daya Perairan, 1(2):131-140.

Ernawati, T., M. Boer, \& Yonvitner. 2014. Biologi Populasi Rajungan (Portunus pelagicus) di Perairan Sekitar Wilayah Pati, Jawa Tengah. Jurnal Bawal, 6(1):31-40.

Hasly, I.R.J., Yusfiandayani, R. \& Mawardi, W. 2019. Respons Rajungan (Portunus pelagicus) Terhadap Warna Cahaya yang Berbeda pada Uji Laboratorium. Jurnal Penelitian Perikanan Indonesia, 25(4):215-224

Hastuti, S., Arifin, S. \& Hidayati, D. 2012. Pemanfaatan Limbah Cangkang Rajungan (Portunus pelagicus) Sebagai Perisa Makanan Alami. Jurnal Agrointek, 6(2):88-96.

Kembaren, D.D. \& Surahman, A. 2018. Struktur Ukuran dan Biologi Populasi Rajungan (Portunus pelagicus Linnaeus, 1758) di Perairan Kepulauan Aru. Jurnal Penelitian Perikanan Indonesia, 24(1):51-60.

Natania, T., Herliany, N.E. \& Kusuma, A.B. 2017. Sktruktur Komunitas Kepiting Biola (Uca spp.) di Ekosistem Mangrove Desa Kahyapu, Pulau Enggano. Jurnal Enggano, 2(1):11-24.

Ningrum, V.P., Ghofar, A. \& Ain, C. 2015. Beberapa Aspek Biologi Perikanan Rajungan (Portunus pelagicus) di Perairan Betahwalang dan Sekitarnya. Jurnal Saintek Perikanan, 11(1):62-71.

Putra, E.M., Pramesti, R., \& Santosa, G.W. 2019. Morfometri Portunus pelagicus Linnaeus, 1758 (malacostra: Portunidae) pada Fase Bulan yang Berbeda di Perairan Betahwalang, Demak. Journal fof Marine Research, 8(2):204-210.

Soliha, E., Rahayu, S.Y.S. \& Triastinurmiatiningsih. 2016. Kualitas Air dan Keanekaragaman Plankton di Danau Cikaret, Cibinong, Bogor. Jurnal Ekologia, 16(2):1-10.

Wiyono, E.S. \& Ihsan. 2015. The Dynamic of Landing Blue Swimming Crab (Portunus pelagicus) Catches in Pangkajene Kepulauan, South Sulawesi, Indonesia. Jurnal AACL Bioflux, 8(2):134-141. 